\title{
Development of Innovative Banking Products and Technologies for People with Disabilities
}

\author{
Elena Travkina \\ Department of Financial Markets and Banks \\ Financial University under the Government of the Russian Federation \\ Moscow, Russia \\ E-mail: evtravkina@fa.ru
}

\author{
Ekaterine Grishina \\ Department of Banking, Money and Credit \\ Saratov Socio-Economic Institute (Branch) of Plehanov \\ Russian University of Economics \\ Saratov, Russia \\ E-mail: gea555@mail.ru
}

\author{
Gyuzal Kurdyumova \\ Department of Banking, Money and Credit \\ Saratov Socio-Economic Institute (Branch) of Plehanov \\ Russian University of Economics \\ Saratov, Russia \\ E-mail:kugyuzel@yandex.ru
}

\begin{abstract}
The article substantiates the need to take into account the features of the segment of people with disabilities in the development of marketing policy of commercial banks and identified barriers to banking services in this segment. The role of the Bank of Russia in the creation of high-quality service for people with disabilities and its impact on the adaptation of banking operations for this segment of customers is studied. The main stages are the creation and implementation of new banking services or a set of interrelated services for customers with disabilities, as well as a number of innovative banking technologies and products for them.
\end{abstract}

Keywords-innovation; banking services and products; innovative banking products; commercial bank

\section{INTRODUCTION}

In the modern world there is a segment of people with disabilities due to the peculiarities of health. Looking at the statistics, it can be noted that this group of people is about $23 \%$ of the world population. In many countries, this group is given special attention in the implementation of national policies: statistics of people with disabilities are kept, their lives, difficulties and needs are studied, and conditions for their quality of life are created.

People with disabilities in terms of banks have low income and health problems, which causes high credit risks for banks. However, the basis for the creation of any civilized society should not exclude this group of people, but rather create the necessary conditions for ensuring normal life, including in the field of quality banking services.

The transition from the traditional economy to digital is a global trend, which includes digital transformation of the financial sector, systematic and progressive introduction of new financial technologies. Flexibility, innovation and speed of implementation of technological changes in the provision of banking products are today one of the main factors of competitiveness for many banks. Banking client base is diverse with its own characteristics and demands [1]. The most uncovered group of Bank clients are people with disabilities.

The majority of commercial banks seek to provide a diverse range of services and products for their customer base. This is done in order to expand its activities, as well as to increase profitability and profitability. In addition, this target setting allows the Bank to increase its competitive position in the market. When providing their services, banks tend to implement them with minimal costs, both for the customer base and for themselves. They also try to set reasonable prices for customers. This is the basis of competition between banks. Customer service, which responds quickly to the needs of a rapidly changing economy, is important from the standpoint of creating a competitive environment [2].

Under the influence of globalization, new types of banking business have emerged and the share of traditional banking services has decreased, in favor of increasing and meeting new customer needs.

Timely and qualitative satisfaction of new customer needs requires continuous improvement and development of new banking products and services. To do this, banks need new channels of their promotion using the latest communication technologies that contribute to the creation of innovative nature of the banking business [3].

In order to improve marketing policy, many commercial banks produce segmentation of their customers. It is very important to take into account the peculiarities of each segment, including retail customers, in the segment of retail customers. In this segment, the most difficult client is a group of people with disabilities. It is worth highlighting the 
following barriers in banking services for this segment of customers:

- physical accessibility problems (lack of ramps and wide corridors in many Bank branches);

- websites of many banks are not adapted to serve visually impaired people;

- ATMs of credit institutions in many cases do not have audio channels, so hard of hearing do not have the ability to lock your card;

- overstatement of basic tariffs for people with disabilities due to increased credit risks;

- lack of training of Bank staff in the data service clients.

In the organization of banking services, as well as in the implementation of traditional and the creation of new banking products and services, banks should take into account the possibility of providing them to people with disabilities, to develop special and effective technologies for their implementation, taking into account the specifics of these customers.

\section{THE CREATION AND INTRODUCTION OF INNOVATIVE} BANKING PRODUCTS AND TECHNOLOGIES IN THE SPECIFICS OF PEOPLE WITH DISABILITIES

Today, the main object in the market of banking services is the sale of banking products and services. In this regard, banking products and services are the Central object of research both in theory and in practice.

Analysis of the essence of banking product, banking service and innovation gives us the right to determine that the concepts of banking innovation are reduced to the results of innovative activities of the Bank and is a set of new banking products and banking services.

We have also formulated our own concept of "new banking product" - a final result of scientific and technical activities of the Bank, which is aimed at improving the individual banking services or to improve the complex of interrelated services targeted to meet the new needs of customers. The purpose of creation and introduction of a new product into banking practice is to create and make a profit, while increasing the competitive advantages of the Bank, as well as meet new customer needs [4].

It should be noted that this concept can be considered for the entire customer base, and for a particular group of customers in particular.

In modern conditions, banks can offer about 200 different types of banking operations, products and services. A wide range of banking operations allows banks to retain old customers and attract new ones.

Marketing research of the banking services market plays a very important role in banking competition. Implementation of marketing activities should start with the analysis of the potential demand for banking services. On the basis of this study, the Bank with a ready portfolio of services provides access to the market. Previously, the Bank calculates the price of each service of its portfolio, taking into account the level of costs and market conditions. After the Bank sells its portfolio of services, it receives a certain profit from this sale. Marketing in the banking sector contributes to the development of banking activities, while it ensures the effective use of monetary resources, taking into account the specifics of the monetary turnover on which all banking activities are based [6]. On the basis of marketing research is compiled and implemented targeted assortment policy of the Bank, which in turn contributes to the growth of profits and reduces commercial risk. The need to study the consumer demand of financial intermediaries focuses on the timely updating of assortment and improvement of quality of provided services. World experience data show that in foreign practice banks spend significant funds (up to $1 \%$ of revenue) for the creation of marketing structures and their successful functioning. We also study the market development trend, clarify customer requests, identify competitors and possible partners, predict the volume of sales of services and profit in the event of a possible change in the market situation.

The determining factor for the marketing of demand for banking services is the study of customers, the study of their needs and opportunities. The study of the distribution market should be carried out in stages:

- conduct analysis of market capacity, the results of distribution and customers ' response to events in the field of distribution policy;

- study competitors and their advantages and disadvantages.

One of the main tasks of market research is to study the needs of the client. In this case, the Bank needs to have information about market conditions in the context of individual segments.

It is very important to segment the market into homogeneous groups of customers. In the process of studying the market and its features, banks determine the main segmentation criteria for their customers. Among such criteria it is possible to allocate: areas of use of this service, levels of the income of clients, behavioral aspect, age and another. In the process of market research can be used methods of observation, customer base survey in relation to the proposed range of banking products and services.

It should be noted that Russian commercial banks when segmenting their customers pay little attention to customers with disabilities, as to serve this group requires large cash resources and costs, in addition, in terms of their income, these customers are not attractive to banks.

\section{THE ROLE AND STRATEGY OF THE BANK OF RUSSIA IN IMPROVING THE QUALITY OF PROVIDING BANKING SERVICES TO PEOPLE WITH DISABILITIES}

If we assess the overall state of financial accessibility in Russia, it can be described as satisfactory. Today, there are a 
number of unresolved problems of financial accessibility in Russia, which are due to the unique features of our country: geographical and demographic characteristics, economic conditions, as well as the youth of the Russian financial market. One of these problems is the development of effective interaction of the banking sector with the segment of the population with disabilities and the penetration of financial services in this segment.

In 2010, Russia signed the Declaration "Seoul consensus for development for universal growth", which was approved by the G20 members. According to the Declaration, countries undertake the following commitments:

- at the state level to develop an action plan to improve access to financial services;

- participate in The G20 global partnership on financial inclusion.

The main key parameters of this strategy are actively implemented by the Bank of Russia in the practice of financial market entities. Thus, the regulator developed indicators of financial accessibility and a system of its evaluation in accordance with the recommendations of the Global partnership on financial accessibility of The G20, the Alliance for financial accessibility and the World Bank.

In addition, the Bank of Russia in modern conditions forms the basis of the system of behavioral supervision. Its creation is one of the strategic objectives of the regulator, which is closely related to the formation of public confidence in the financial market, to ensure the implementation of quality and affordable financial services and the overall development of the financial market. The main objective of behavioral surveillance is to create an environment in which financial sector participants will provide their clients with complete information about their products, as well as have in their assortment only those products that they really need. Conduct of behavioral supervision will help to increase customer satisfaction in the financial market, as well as provide an opportunity for consumers to make the right choice in favor of the best Bank offer and services.

It should be noted that the Bank of Russia in the process of transition to the model of behavioral supervision published an information letter addressed to credit institutions, which contained recommendations on the process of informing consumers about the financial instruments and services provided to them. In accordance with the chosen concept, the regulator assigns an important role to such a group of consumers of banking services as people with disabilities. The working group, which includes the Bank of Russia, representatives of the Federal Assembly, ministries and agencies, public organizations of people with disabilities, financial institutions, as well as higher education institutions, is engaged in the issue of increasing financial accessibility for people with disabilities and people with limited mobility. The Central Bank is developing a system of sanctions for banks that are not adapted for people with disabilities. In the future, banks that do not improve their offices and their services for people with disabilities will receive instructions from the regulator. That is, commercial banks will be required to eliminate violations identified by the auditors of the Bank of Russia in the course of inspections. If banks repeatedly fail to comply with the requirements of the regulator, they may lose their license. In summary, the main key elements of the Bank of Russia's strategy to improve financial accessibility in the Russian Federation in 2018-2020 can be presented in the form of "Table I".

TABLE I. BASIC ELEMENTS OF THE BANK OF RUSSIA'S STRATEGY TO IMPROVE FINANCIAL ACCESSIBILITY IN THE RUSSIAN FEDERATION IN 2018-2020 (IN THE SEGMENT OF PEOPLE WITH DisABILITIES)

\begin{tabular}{|c|c|c|}
\hline Priorities & Content & Expected result \\
\hline $\begin{array}{l}\text { improving } \\
\text { understanding of } \\
\text { the needs of } \\
\text { people with } \\
\text { disabilities }\end{array}$ & $\begin{array}{l}\text { - conducting research aimed at } \\
\text { identifying specific limitations } \\
\text { and needs; } \\
\text { - study of financial behavior } \\
\text { models. }\end{array}$ & $\begin{array}{l}\text { expanding } \\
\text { financial } \\
\text { inclusion } \\
\text { people of } \\
\text { disabilities }\end{array}$ \\
\hline $\begin{array}{lr}\text { promoting } & \text { the } \\
\text { development } & \text { of } \\
\text { financial } & \\
\text { products } & \text { and } \\
\text { services } & \text { for } \\
\text { people } & \text { with } \\
\text { disabilities } & \end{array}$ & $\begin{array}{l}\text { - development of adapted } \\
\text { financial products; } \\
\text { - evaluation and barrier } \\
\text { analysis of the regulations } \\
\text { concerning which are } \\
\text { associated with the } \\
\text { development of products with } \\
\text { low price; } \\
\text { - evaluation of proposals to } \\
\text { modify the regulation in order } \\
\text { to reduce the occurrence of } \\
\text { possible risks and overcome } \\
\text { the barrier standards; } \\
\text { - expansion of channels of } \\
\text { interaction between } \\
\text { commercial banks and } \\
\text { customers with the exception } \\
\text { of discrimination of any } \\
\text { segment of customers, } \\
\text { including customers with } \\
\text { sensory limitations, as well as } \\
\text { problems with the } \\
\text { musculoskeletal system; } \\
\text { - development of remote } \\
\text { identification mechanisms. }\end{array}$ & $\begin{array}{l}\text { removing } \\
\text { barriers to } \\
\text { financial services } \\
\text { and eliminating } \\
\text { discrimination } \\
\text { against these } \\
\text { customers }\end{array}$ \\
\hline
\end{tabular}

The development of digital financial accessibility is of particular importance for Bank customers with disabilities. In this direction, the Bank of Russia is also actively working:

- creation and implementation of the platformmarketplace for the sale of financial services and products will help to expand the possibility of obtaining services by customers in a single window, as well as eliminate barriers to access to financial services and products for customers with disabilities;

- the creation and implementation of fast payments will help to expand the possibility of online transfers in the financial market in real time using simple identifiers of recipients of funds (for example, mobile phone number, QR-code);

- creation and implementation of a unified system of identification, authentication and biometric system, which represent a special infrastructure based on the use of multi-factor remote identification and analysis of data from the state information system, as well as 
biometric data to enable remote provision of financial services.

Thus, the Bank of Russia is doing a great job to provide quality service to customers with disabilities. Its activities in the field of creation and development of digital financial infrastructure will strengthen the penetration of financial products and services in various segments of banking customers, including the segment of customers with disabilities throughout the Russian Federation.

IV. FORMATION AND REALIZATION OF STRATEGY OF INNOVATIVE PRODUCTS AND TECHNOLOGIES FOR PEOPLE WITH DISABILITIES IN THE ACTIVITIES OF RUSSIAN COMMERCIAL BANKS

Strategy for the sale of banking products and services plays a special role in the formation of the Bank's stable competitive position in the market of banking services. This strategy makes it possible to increase sales of banking products and services, to increase profits from the use of the banking brand, to form a reputation of a reliable Bank. The special role of the strategy of promotion of banking services in the marketing activities of a commercial Bank determines its place in the system of banking management in subordination to marketing goals and objectives of management. In the field of promotion of new banking products and technologies for customers with disabilities, banks need to create a special strategy taking into account the specifics of these customers.

In a generalized form, the process of creating, promoting and implementing new banking products can be represented by a set of the following stages (see "Fig. 1").

$$
\begin{aligned}
& \begin{array}{c}
\text { The idea of creating an improved separate banking service or an improved set of interrelated services } \\
\text { for customers with disabilities }
\end{array} \\
& \begin{array}{|c}
\text { An advanced individual banking services or advanced complex of interrelated services for } \\
\text { clients with disabilities }
\end{array} \\
& \hline \begin{array}{c}
\text { An enhanced private banking services or improved complex of interrelated services for } \\
\text { customers with disabilities improved complex of interrelated services for customers with } \\
\text { disabilities }
\end{array} \\
& \hline \begin{array}{c}
\downarrow \\
\text { Extension selects advanced private banking services or improved complex of interrelated } \\
\text { services for customers with disabilities }
\end{array} \\
& \hline
\end{aligned}
$$

Fig. 1. The main stages of creation and implementation of new banking services or a set of interrelated services for customers with disabilities.

The main strategic directions of development of the existing commercial Bank banking services for customers with disabilities are:

- ensuring equal access for all customers to banking products and services, which is possible in the development of inclusive service standards;

- adaptation of all products, self-service devices and service points of the Bank for customers with disabilities without exception.

Analysis of banking services of Russian banks in the segment of customers with disabilities can be identified the development and implementation of the following innovative banking technologies and products:

- registration and receipt of banking services at home;

- development and implementation of chat technology with the contact center operator;

- introduction of remote sign language translation services;
- adaptation of banking sites to meet the requirements for contrast and increase the text, voice graphic elements of the site, the use of simplified navigation;

- adaptation of interfaces of mobile applications for customers with visual impairment (using the function of reading text narrator).

When implementing the strategy for the sale of banking products and services in the segment of customers with disabilities in a commercial Bank, special attention should be paid to increasing the level of empathy of employees in dealing with people with disabilities.

\section{CONCLUSION}

Banks are moving away from the classic financial services provider model and towards a global ecosystem model. The main task of creating this ecosystem is the selection and implementation of effective, efficient and convenient services for customers in order to meet their daily needs. To do this, it is necessary to combine into a single platform the range of all partners of the Bank that provide 
financial and non-financial services. The formation of such a unified platform will provide an opportunity to offer complex products to various layers of customers, as well as to increase the level of satisfaction with the service and maintain it at a high level at all stages of the banking product and service creation chain. In order to create a civilized banking service in the practice of commercial banks in the implementation of its marketing strategy, as well as in the formation and implementation of new banking products and technologies, special attention should be paid to customers with disabilities not only in terms of adapting the processes of banking services, but also to introduce special convenient products.

\section{REFERENCES}

[1] Ebersberger B., Bloch C., Herstad S.J., Van De Velde E, "Open innovation practices and their effect on innovation performance," International Journal of Innovation and Technology Management, 2012, vol. 6, p. 1250040.

[2] Jaap W. B. Bos, James W. Kolari, Ryan C. R. van Lamoen, "Competition and innovation: Evidence from financial services," Journal of Banking \& Finance, 2013, vol.5, p.1590-1601.

[3] James B. Ang, "Innovation and financial liberalization,"Journal of Banking \& Finance, 2014, vol.47, p.214-229.

[4] James B. Ang, Sanjesh Kumar, "Financial development and barriers to the cross-border diffusion of financial innovation," Journal of Banking \& Finance, 2014, vol.39, p.43-56

[5] Konstantinos N. Baltas, George Kapetanios, EfthymiosTsionas, Marwan Izzeldin, "Liquidity creation through efficient M\&As: A viable solution for vulnerable banking systems? Evidence from a stress test under a panel VAR methodology," Journal of Banking \&Finance, 2017, vol.83, p.36-56.

[6] Semernina, Y.V., Yakunina, A.V., Nesterenko, E.A., Yakunin, S.V., Korobov, E.A., "Evaluation of reinvestment risk for bond portfolios", CEUR Workshop Proceedings, 2018, p.184-192. 